Jurnal Kiprah 8 (2) (2020) 105-112
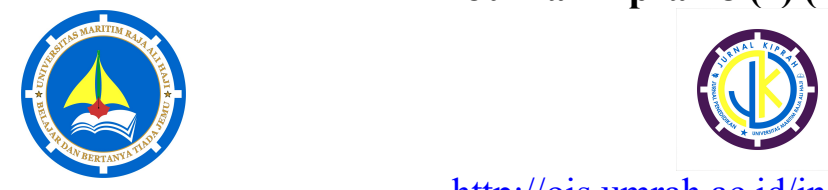

http://ojs.umrah.ac.id/index.php/kiprah

p-ISSN 2354-7278 | e-ISSN 2580-6947

\title{
Realistic Mathematics Education Principles for Designing a Learning Sequence on Number Patterns
}

\author{
Al Jupri", Dian Usdiyana, Ririn Sispiyati \\ Program Studi Pendidikan Matematika, Universitas Pendidikan Indonesia, Bandung, Indonesia \\ Pengiriman: 24/06/2020; Diterima: 17/10/2020; Publikasi: 20/11/2020
}

DOI: 10.31629/kiprah.v8i2.2358

\begin{abstract}
Abstrak
Pola bilangan adalah salah satu topik matematika untuk siswa sekolah menengah pertama yang mengaitkan antara aritmetika dan aljabar. Topik ini selain menjadi jembatan antara berpikir aritmetik dan berpikir aljabar, juga mengembangkan landasan berpikir matematis siswa. Oleh karena itu, pembelajaran pada topik ini perlu didesain secara bermakna. Penelitian ini bertujuan untuk mendesain bahan ajar pola bilangan dengan menerapkan prinsip pendidikan matematika realistik yang menekankan kebermaknaan dalam belajar. Untuk mencapai tujuan ini, penelitian ini menggunakan metode penelitian desain, fase desain awal, yang dilakukan dengan langkah sebagai berikut. Pertama, studi literatur tentang pembelajaran pola bilangan dilakukan untuk mengetahui berbagai kesulitan yang dihadapi siswa, mengetahui hasil-hasil studi yang relevan, dan teori pendidikan matematika realistik (PMR). Kedua, kami melakukan pengamatan terbatas terhadap buku pelajaran matematika untuk melihat urutan pembelajaran topik pola bilangan. Ketiga, berdasarkan dua langkah sebelumnya disusunlah urutan pembelajaran pola bilangan dengan menerapkan prinsip teori PMR, khususnya prinsip realitas, prinsip tingkatan, dan prinsip keterkaitan. Hasil dari penelitian ini adalah sebuah lintasan belajar topik pola bilangan berdasarkan tiga prinsip teori PMR. Lintasan belajar ini terdiri atas tiga aktivitas pembelajaran yang disusun secara bermakna: Kaitan antara pola dan bilangan, eksplorasi bilangan, dan generalisasi pola bilangan. Dapat disimpulkan bahwa tiga prinsip PMR membantu dalam proses desain untuk menghasilkan bahan ajar ini.
\end{abstract}

Kata kunci: pendidikan aljabar; pendidikan matematika realistik; penelitian desain; pola bilangan

\begin{abstract}
The number pattern is one of mathematics topics taught for junior high school students that relate between arithmetic and algebra domain. This topic not only bridges arithmetical and algebraic thinking, but also develops student mathematical thinking. Therefore, the learning for this topic should be designed meaningfully. This research aims to design a learning sequence on the number patterns using principles of Realistic Mathematics Education (RME). To do this, we used design research method, particularly the preliminary design phase, with the following three steps. First, literature study was conducted to collect student difficulties in the learning of number patterns, relevant studies, and the theory of RME. Second, we observed Indonesian mathematics textbooks addressing the number patterns to see a learning sequence for this topic. Finally, we designed a learning sequence for the number patterns using the RME principles, particularly the reality principle, level principle, and intertwinement principle. The result of this research includes the learning sequence for the number patterns according to the RME principles, which consists of three activities: relationship between patterns and numbers; exploration of numbers; and generalization of number patterns. We conclude that the three principles of RME are fruitful for designing a meaningful learning sequence for the topic of number patterns.
\end{abstract}

Keywords: algebra education; design research; number patterns; realistic mathematics education

*Email Korespondensi: aljupri@upi.edu 


\section{INTRODUCTION}

Algebra is one of mathematics domains that should be learned by junior high school students, not only in Indonesia (Kemendikbud, 2013), but also in other countries (Drijvers, 2003; Drijvers, Goddijn \& Kindt, 2010; Katz, 2007). Learning algebra is, however, difficult for most students (Drijvers, 2003; Jupri, 2015; Katz, 2007). The difficulty encountered by not only advanced algebra students, but also students of initial algebra learning (Jupri, Drijvers \& Van den HeuvelPanhuizen, 2014; 2015). Initial algebra topics that are difficult for most of students include linear equation and inequality in one variable, operations on algebraic expressions, and number patterns (Jupri, 2015). This difficulty should be overcome, for instance, by designing a meaningful learning sequence for students.

Previous studies on the design of learning sequence on algebra, particularly on the topic of number patterns, focused on the design of learning related to a local culture (Disnawati \& Nahak, 2019), according to a general learning model (Maryati, 2018), and general criteria of validity of a learning material (Ula \& Fadila, 2018). These studies, however, are not designed according to a domain specific theory of didactic of mathematics. As a consequence, the learning sequence sometimes does not consider the relationship between the development of student thinking and the didactic of mathematics.

This current research proposes to design an algebra learning sequence, on the topic of number patterns, according to the domain specific theory of mathematics education, particularly the theory of Realistic Mathematics Education (RME) (Van den Heuvel-Panhuizen \& Drijvers, 2014). The RME theory is used because it is considered to be successful in guiding the design of learning materials for students in the Netherlands and has been adapted in the United States (Meyer, 2001) and other countries, including in Indonesia (Jupri, 2015; Jupri, Usdiyana, \& Sispiyati, 2019; 2020; Sembiring, Hadi \& Dolk, 2008). Taking this into account, this research aims to design an algebra learning sequence on the topic of number patterns using principles of the RME theory.

For the design process, in line with the previous studies (Jupri, Usdiyana \& Sispiyati, 2019; 2020), we propose to use three principles of the RME theory in the design process: the reality principle, the level principle, and the intertwinement principle. From the perspective of the reality principle, mathematics learning is suggested to start from meaningful and realistic problems that need to be mathematized by students (Van den Heuvel-Panhuizen \& Drijvers, 2014; Van den Heuvel-Panhuizen, 2003). Students should produce their own mathematization under the guidance of the teacher or the learning material. Mathematization concerns an activity of translating a realistic problem into a symbolic mathematics problem and reconstruct the symbolic problem within the world of mathematics (Van den HeuvelPanhuizen \& Drijvers, 2014; Jupri \& Drijvers, 2016).

According to the level principle, in the learning process, students should pass through an increasing level of understanding: from context-related situations toward more abstract understanding (Van den Heuvel-Panhuizen \& Drijvers, 2014). This should be provided in the learning material, for instance, through a sequence of tasks that represents this principle.

In the view of the intertwinement principle, various mathematical content domains such as arithmetic, geometry, and algebra are considered to be integrated rather than isolated topics (Jupri, 2017; Van den Heuvel-Panhuizen \& Drijvers, 2014). So, in the design process, the learning sequence should present integrated mathematical content domains in conveying mathematical concepts.

\section{RESEARCH METHOD}

To achieve the aim of this research, namely to design an algebra learning sequence on the topic of number patterns using principles of Realistic Mathematics Education (RME), we used design research method (Bakker \& Van Eerde, 2015; Jupri, Usdiyana, $\&$ Sispiyati, 2019), particularly the preliminary 
design phase, with the following three steps. First, we carried out a literature study to comprehend student difficulties in the learning of number patterns, to obtain relevant studies related to algebra learning, and to understand the theory of RME.

In the second step, we observed several mathematics textbooks, published by the Indonesian government (e.g., Djumanta \& Susanti, 2008; Masduki \& Utomo, 2007; Soedjadi \& Moesono, 1995) and a private publisher (e.g., Budhi, 2007), addressing the topic of number patterns. This observation was carried out to conceive the learning sequence for this topic and to obtain ideas for conducting a design process. Whereas the topic of number patterns should be an important foundation for understanding next algebra topics, we observed it is only a minor topic for conveying the topic of sequence and series of numbers. This fact supported our aim in designing a meaningful learning sequence. As information, currently, the topic of number pattern is taught for grade VIII of Indonesian students (Kemendikbud, 2013).

Finally, we designed a learning sequence for the number patterns using the RME principles, particularly the reality principle, the level principle, and the intertwinement principle (Van den HeuvelPanhuizen \& Drijvers, 2014). The sequence of learning that we designed consists of three subsequent activities: the relationship between patterns and numbers; an exploration of numbers and their properties; and generalization of number patterns. Since this topic concerns an initial algebra, the main context that we use for the design is the context of numbers. According to the reality principle, the context of numbers is realistic because it can be imagined by junior high school students' minds. The sequence of learning represents the level principle because it provides algebra tasks from concrete to a more abstract mathematical situations. The intertwinement principle appears in the fact that the context of numbers has many relationships with figural patterns, numerical patterns, and generalization of numbers toward symbolic formulas.

\section{RESULTS AND DISCUSSION}

This section presents the result and the discussion of the design process. The learning sequence on the topic of number patterns includes three learning activities: Finding relationships between patterns and numbers; Exploring numbers and their properties; and Generalizing number patterns.

\section{Finding Relationship between Patterns and Numbers}

For the first learning activity, that is, finding the relationships between patterns and numbers, the learning process starts from an activity of observing a pattern of dots, finding the number of dots in each figural pattern, and predicting the number of dots for a next figural pattern. After students get used to see the relationships between patterns and numbers, next students are expected to be able to predict a next number if they are given a sequence of numbers. Typical tasks for the first learning activity are shown in Table 1 .

For the Task 1, students are expected to be able to predict a next dot pattern and the corresponding number of dots. Based on the dot patterns observed in the first column, students can observe for instance the following number pattern on the right column:

$1=1$

$3=1+2$

$6=1+2+3$

$10=1+2+3+4$

So, the next number of dots should be 15 because $15=1+2+3+4+5$.

For the Task 2, students are expected to be able to predict next three numbers. However, if students find it difficult to see the pattern, students can use dot patterns to draw each given number. From this strategy, they are expected to observe the following pattern:

$1=1$

$4=1+3$

$9=1+3+5$ 
$16=1+3+5+7$

$25=1+3+5+7+9$.

Using the above pattern, the next three numbers can be obtained easily. If students can see the pattern of the given numbers directly as a square number, then of course the next three numbers are easy to find.

Table 1. Typical tasks for the first learning activity

Task 1. Continue the following dot pattern and find the next corresponding number of dots.

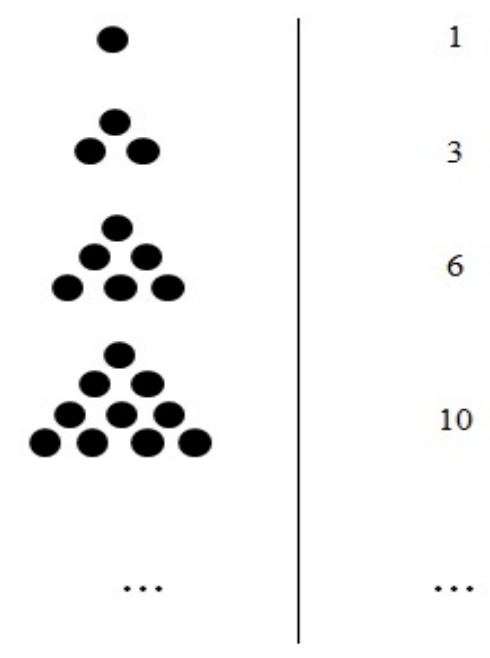

Task 2. Continue the following number pattern. Find next three numbers.

$1,4,9,16,25, \ldots, \ldots, \ldots$

From the RME perspective, the first learning activity uses the reality principle, i.e., using the context of numbers according to dots or figural patterns. This context, in our view, is considered to be meaningful and realistic for students (Jupri, 2017; Van den HeuvelPanhuizen \& Drijvers, 2014).

\section{Exploring Numbers and Their Properties}

In the second learning activity, students are expected to explore sequences of numbers and their properties from the given arrangement of numbers. From the perspective of the level principle (Van den HeuvelPanhuizen \& Drijvers, 2014) this second learning activity is a continuation of the first activity in which students are expected to use previous experiences to find as many as possible sequences of numbers and their corresponding properties. Table 2 presents typical tasks for this activity.

Table 2. Typical tasks for the second learning activity

Task 3. Consider the following arrangement of numbers and answer the following questions.

\begin{tabular}{|c|c|c|c|c|}
\hline 1 & 3 & 5 & 7 & 9 \\
\hline 11 & 13 & 15 & 17 & 19 \\
\hline 21 & 23 & 25 & 27 & 29 \\
\hline 31 & 33 & 35 & 37 & 39 \\
\hline 41 & 43 & 45 & 47 & 49 \\
\hline
\end{tabular}

(a) Consider the sequence of numbers on column 3. Describe properties of this sequence and find next three numbers.

(b) Consider the sequence of numbers on the main diagonal. Describe properties of this sequence and find next three numbers.

(c) Find other sequences of numbers (as many as you can) and describes their properties.

Task 4. Consider the following cases.

$2 \times 2=2+2$

$3 \times \frac{3}{2}=3+\frac{3}{2}$

$4 \times \frac{4}{3}=4+\frac{4}{3}$

$5 \times \frac{5}{4}=5+\frac{5}{4}$

$6 \times \frac{6}{5}=6+\frac{6}{5}$

Can you find the pattern? Find other three pairs of numbers having the same properties as the cases above.

For the Task 3, for instance Task 3(a), students are expected to see that the sequence 
of numbers $5,15,25,35,45$ is a multiple of 5 in which the last digit is 5 , and the difference between two consecutive terms is 10 . So, they can determine next three numbers easily, i.e., 55,65 , and 75 . The ability to explore properties of numbers is based upon experiences from the first learning activity. Next, students are expected to be able to answer the other two questions in a similar fashion.

For the Task 4, students are expected to find a pattern of number relationships. If they find it, they will get three other pairs, such as: 7 and 7/6; 8 and 8/7; 9 and 9/8. This pattern for instance can be found by the exploration shown in Figure 1. After finding the three next pairs of numbers, students are expected to be able to find other pairs.

$$
\begin{aligned}
& 2 \times 2=2 \times 1+2 \Leftrightarrow 2 \times 2=2+2 . \\
& \text { [Both sides are divided by } 1 \text { ] } \\
& 3 \times 3=3 \times 2+3 \Leftrightarrow 3 \times \frac{3}{2}=3+\frac{3}{2} \text {. } \\
& \text { [Both sides are divided by } 2 \text { ] } \\
& 4 \times 4=4 \times 3+4 \Leftrightarrow 4 \times \frac{4}{3}=4+\frac{4}{3} \text {. } \\
& \text { [Both sides are divided by } 3 \text { ] } \\
& 5 \times 5=5 \times 4+5 \Leftrightarrow 5 \times \frac{5}{4}=5+\frac{5}{4} . \\
& \text { [Both sides are divided by } 4 \text { ] } \\
& 6 \times 6=6 \times 5+6 \Leftrightarrow 6 \times \frac{6}{5}=6+\frac{6}{5} . \\
& \text { [Both sides are divided by } 5 \text { ] } \\
& 7 \times 7=7 \times 6+7 \Leftrightarrow 7 \times \frac{7}{6}=7+\frac{7}{6} \text {. } \\
& \text { [Both sides are divided by } 6 \text { ] } \\
& 8 \times 8=8 \times 7+8 \Leftrightarrow 8 \times \frac{8}{7}=8+\frac{8}{7} \text {. } \\
& \text { [Both sides are divided by 7] } \\
& 9 \times 9=9 \times 8+9 \Leftrightarrow 9 \times \frac{9}{8}=9+\frac{9}{8} \text {. } \\
& \text { [Both sides are divided by } 8 \text { ] }
\end{aligned}
$$

Figure 1. An exploration of numbers for Task 4

The above exploration activity, in the perspective of RME, uses the level principle in which students are expected to work on a more abstract level than the previous first learning activity (Jupri, Usdiyana, \& Sispiyati, 2019). The second activity is considered to be more abstract than the first activity because students work on only numbers without any relation to dots or other figural patterns.

\section{Generalizing Number Patterns}

After doing the previous two activities, students are expected to be able to make generalizations of number patterns in the third activity. Typical tasks for doing generalizations are shown in Table 3.

Table 3. Typical tasks for the third learning activity

Task 5. Find the $100^{\text {th }}$ term for the following sequence of numbers. (Hint: Find the formula for the $n$th term.)

$$
1,3,6,10,15, \ldots
$$

Task 6. Find the formula for the $n$th term for the following sequence of numbers.

$$
2,6,10,14,18, \ldots
$$

For solving the Task 5, rather than finding the $100^{\text {th }}$ term manually, students are suggested to find a formula for the $n$th term first. Next, using the formula, they can calculate the $100^{\text {th }}$ term easily. For this task, students are expected to use their experiences of exploring number patterns in the second activity to find a formula for the $n$th term. So, they would for instance find the formula by doing an exploration shown in Figure 2.

By recognizing the emerging pattern, students are expected to conclude that the formula for the $n$th term for the sequence of numbers in the Task 5 is $n \times(n+1) / 2$. Therefore, the $100^{\text {th }}$ term of the sequence can be calculated easily, i.e., $100 \times 101 / 2=5050$. 
A. Jupri, D. Usdiyana, R. Sispiyati / Jurnal Kiprah 8 (2) (2020) 105-112

\begin{tabular}{|ccc|}
\hline No & $\boldsymbol{n}$ th term & Pattern \\
\hline 1 & 1 & $(1 \times 2): 2$ \\
2 & 3 & $(2 \times 3): 2$ \\
3 & 6 & $(3 \times 4): 2$ \\
4 & 10 & $(4 \times 5): 2$ \\
5 & 15 & $(5 \times 6): 2$ \\
6 & 21 & $(6 \times 7): 2$ \\
7 & 28 & $(7 \times 8): 2$ \\
$\cdots$ & $\ldots$ & $\ldots$ \\
\hline
\end{tabular}

Figure 2. An exploration to find a formula for the sequence of numbers in Task 5

After experiencing the exploration of finding a formula in the Task 5, in the Task 6 students are directly asked for finding a formula for the $n$th term of the sequence of numbers. An example of exploration that might emerge from students' work is shown in Figure 3. By recognizing the emerging pattern, students would find that the $n$th term formula for the sequence of numbers is $4 \times n-2$.

\begin{tabular}{|ccc|}
\hline No & $\boldsymbol{n}$ th term & Pattern \\
\hline 1 & $2=4-2$ & $1 \times 4-2$ \\
2 & $6=8-2$ & $2 \times 4-2$ \\
3 & $10=12-2$ & $3 \times 4-2$ \\
4 & $14=16-2$ & $4 \times 4-2$ \\
5 & $18=20-2$ & $5 \times 4-2$ \\
6 & $22=24-2$ & $6 \times 4-2$ \\
7 & $26=28-2$ & $7 \times 4-2$ \\
$\cdots$ & $\ldots$ & $\ldots$ \\
\hline
\end{tabular}

Figure 3. An exploration to find a formula for the sequence of numbers in Task 6

In this third activity, the learning process was designed coherently according to the previous two learning activities, and is focused on making generalizations. The activity of generalizing, in this case finding algebraic formulas, is an important algebraic thinking that bridges between arithmetic and algebra (Dekker \& Dolk, 2010; Drijvers, Dekker, \& Wijers, 2010; Jupri, 2015). From the perspective of the RME theory, this learning activity has used mainly the intertwinement principle as an addition to the level principle (Van den Heuvel-Panhuizen 2003; Jupri, 2017). The process of finding and using algebraic formulas, which use variables as generalized arithmetic (Jupri, Drijvers, \& Van den Heuvel-Panhuizen, 2014), is an example of the intertwinement between arithmetic and algebra. This intertwinement provides an example of what is so-called horizontal mathematization, that is, translating from a realistic problem into a symbolic world of mathematics (Jupri \& Drijvers, 2016; Van den Heuvel-Panhuzen \& Drijvers, 2014).

\section{CONCLUSIONS}

From the description in the previous section, we draw the following conclusions. The designed learning sequence for the topic of number patterns includes three activities: finding relationships between patterns and numbers; exploring numbers and their properties; and generalizing number patterns. The main context used in the learning sequence is numbers - which is relatively realistic for junior high school students' mind. The context of numbers bridges between the world of arithmetic and the world of symbolic algebra.

Three principles of the RME theory, i.e., the reality principle, the level principle, and the intertwinement principle, play an important role in the design process. The use of numbers as the main context represents the reality principle because numbers are imaginable in students' mind. The level principle is represented in the increasing order of abstractness of the learning sequence. Finally, the intertwinement principle is apparent in the activity of doing generalization. In particular, the generalization activity bridges clearly between the world of arithmetic and of algebra. Considering this promising design, we wonder if the learning 
sequence on the topic of number patterns can be implemented in the learning process, in a future research, to guide students to understand algebra.

\section{ACKNOWLEDGMENTS}

This study was funded by Deputi Bidang Penguatan Riset dan Pengembangan, Kementerian Riset dan Teknologi/Badan Riset dan Inovasi Nasional, Republik Indonesia through Penelitian Terapan Unggulan Perguruan Tinggi research scheme, year 2020 .

\section{REFERENCES}

Bakker A., \& Van Eerde, D. (2015). An Introduction to Design-Based Research with an Example From Statistics Education. In: Bikner-Ahsbahs A., Knipping C., Presmeg N. (eds) Approaches to Qualitative Research in Mathematics Education. Advances in Mathematics Education. Springer, Dordrecht. Doi: https://doi.org/10.1007/978-94-0179181-6 16

Budhi, W. S. (2007). Matematika untuk SMP kelas IX semester 2. Jakarta: Erlangga.

Dekker, T., \& Dolk, M. (2010). From arithmetic to algebra. In P. Drijvers (Ed.), Secondary school algebra education: Revisiting topics and themes and exploring the unknown (pp. 69-87) Rotterdam, The Netherlands: Sense Publishers.

Disnawati, H., \& Nahak, S. (2019). Pengembangan lembar kerja siswa berbasis Etnomatematika tenun Timor pada materi pola bilangan. Jurnal Elemen, 5(1), 64-79. Doi: 10.29408/jel.v5i1.1022.

Drijvers, P. (2003). Learning algebra in a computer algebra environment: Design research on the understanding of the concept of parameter (Doctoral dissertation, University of Utrecht, The Netherlands). Retrieved from: https://dspace.library.uu.nl/handle/1874/ 886.

Drijvers, P., Goddijn, A., \& Kindt, M. (2010). Algebra education: Exploring topics and themes. In P. Drijvers (Ed.), Secondary school algebra education: Revisiting topics and themes and exploring the unknown (pp. 1-26). Rotterdam, The Netherlands: Sense Publishers.

Drijvers, P., Dekker, T., \& Wijers, M. (2010). Patterns and formulas. In P. Drijvers (Ed.), Secondary school algebra education: Revisiting topics and themes and exploring the unknown (pp. 89100). Rotterdam, The Netherlands: Sense Publishers.

Djumanta, W., \& Susanti, D. (2008). Belajar matematika aktif dan menyenangkan untuk kelas IX sekolah menengah pertama/madrasah tsanawiyah. Jakarta: Pusat Perbukuan, Departemen Pendidikan Nasional.

Jupri, A., Drijvers, P., \& Van den HeuvelPanhuizen, M. (2014). Difficulties in initial algebra learning in Indonesia. Mathematics Education Research Journal, 26(4), 683-710. Doi: 10.1007/s13394-013-0097-0.

Jupri, A. (2015). The use of applets to improve student performance in algebra (Doctoral dissertation, University of Utrecht, The Netherlands). Retrieved from:

https://dspace.library.uu.nl/handle/1874/ 303950

Jupri, A., Drijvers, P., \& Van den HeuvelPanhuizen, M. (2015). Improving grade 7 students' achievement in initial algebra through a technology-based intervention. Digital Experience in Mathematics Education, 1(1), 2858. DOI: $10.1007 / \mathrm{s} 40751-015-0004-2$

Jupri，A., \& Drijvers, P. (2016). Student difficulties in mathematizing word problems in algebra. Eurasia Journal of Mathematics, Science, and Technology Education, 12(9), 2481-2502. Doi: https://doi.org/10.12973/eurasia.2016.12 
A. Jupri, D. Usdiyana, R. Sispiyati / Jurnal Kiprah 8 (2) (2020) 105-112

$\underline{99 \mathrm{a}}$

Jupri, A. (2017). From geometry to algebra and vice versa: Realistic mathematics education principles for analyzing geometry tasks. In AIP Conference Proceedings (Vol. 1830, No. 1, p. 050001). AIP Publishing. Doi: https://doi.org/10.1063/1.4980938

Jupri, A., Usdiyana, D., \& Sispiyati, R. (2019). Designing an algebra learning sequence: the case of operations on algebraic expressions. Journal of Physics: Conference Series, 1280, 1-5. Doi: $10.1088 / 1742-6596 / 1280 / 4 / 042038$

Jupri, A., Usdiyana, D., \& Sispiyati, R. (2020). Peran representasi matematis dalam pembelajaran perkalian bentuk aljabar melalui pendekatan matematika realistik. Jurnal Elemen, 6(1), 89-98. Doi: 10.29408/jel.v6i1.1716.

Katz, V. J. (2007). Gateway to a Technological Future. United States of America: The Mathematical Association of America.

Kemendikbud (2013). Kurikulum 2013. Kompetensi Dasar: Sekolah Menengah Pertama (SMP)/Madrasah Tsanawiyah (MTs). Jakarta: Kementerian Pendidikan dan Kebudayaan.

Maryati, I. (2018). Penerapan model pembelajaran berbasis masalah pada materi pola bilangan di kelas VII sekolah menengah pertama. Mosharafa: Jurnal Pendidikan Matematika, 7(1), 63-74.

Masduki., \& Utomo, I. B. (2007). Matematika untuk SMP \& MTs kelas IX. Jakarta: Pusat Perbukuan Nasional, Departemen
Pendidikan Nasional.

Meyer, M. R. (2001). Representation in realistic mathematics education. In A.A. Cuoco, \& F.R. Curcio (Eds.), The roles of representation in school mathematics (pp. 238-250). Reston, Virginia: National Council of Teachers of Mathematics.

Sembiring, R. K., Hadi, S., \& Dolk, M. (2008). Reforming mathematics learning in Indonesian classrooms through RME. ZDM, 40(6), 927-939. Doi: https://doi.org/10.1007/s11858-008$\underline{0125-9}$

Soedjadi, R., \& Moesono, D. (1995). Matematika untuk sekolah lanjutan tingkat pertama kelas 3. Jakarta: Departemen Pendidikan dan Kebudayaan.

Ula, I. R., \& Fadila, A. (2018). Pengembangan E-Modul berbasis learning content development system pokok bahasan pola bilangan SMP. Desimal: Jurnal Matematika, 1(2), 201-207.

Van den Heuvel-Panhuizen, M. (2003). The didactical use of models in realistic mathematics education: An example from a longitudinal trajectory on percentage. Educational studies in Mathematics, 54(1), 9-35. Doi: https://doi.org/10.1023/B:EDUC.00000 05212.03219.dc

Van den Heuvel-Panhuizen, M., \& Drijvers, P. (2014). Realistic mathematics education. In S. Lerman (Ed.), Encyclopedia of mathematics education, 713-717. Doi: 10.1007/978-94-0074978-8. 